\title{
Peran Pengungkapan Csr Dan Mekanisme Geg Pada Kinerja Keuangan Terhadap Nilai Perusahaan
}

\author{
Lela Nurlaela Wati ${ }^{1}$, Galang Raindo Syahdam ${ }^{2}$ Bono Prambudi ${ }^{3}$ \\ STIE Muhammadiyah Jakarta, \\ 11ela@stiemj.ac.id; lela_nwm@yahoo.com \\ 2raindo21@gmail.com \\ bono@stiemj.ac.id
}

\begin{abstract}
ABSTRAK
Penelitian ini bertujuan untuk meneliti peran moderasi pengungkapan Corporate Social Responsibility (CSR) dan mekanisme good corporate governance (GCG) pada pengaruh kinerja keuangan terhadap nilai perusahaan. Penelitian ini menggunakan data dari 87 perusahaan manufaktur yang terdaftar dalam Indonesian Stock Exchange (IDX) selama periode 2010 sampai dengan 2015 dengan menggunakan Moderating Regression Analysis (MRA). Hasil penelitian menunjukkan bahwa kinerja keuangan perusahaan memiliki pengaruh yang signifikan terhadap nilai perusahaan. Pengungkapan CSR mampu memoderasi hubungan antara kinerja keuangan terhadap nilai perusahaan, namun kepemilikan manajerial sebagai mekanisme GCG tidak mampu memoderasi hubungan antara kinerja terhadap nilai perusahaan. CSR dapat membangun citra positif perusahaan dimata investor maupun masyarakat, karena dengan mengungkapkan informasi sosialnya akan menarik investor dan berdampak pada meningkatnya nilai perusahaan.
\end{abstract}

Kata kunci :

Corporate Sosial Responsibility, Good Corporate Governance, Kinerja Keuangan, Nilai Perusahaan

\begin{abstract}
This study aims to examine the effect of corporate social responsibility disclosure (CSR) and good corporate governance mechanism to the relationship of financial performance with the firm value. This study used data from 87 manufacturing companies listed in the Indonesian Stock Exchange (IDX) during the period 2010 to 2015 with Moderating Regression Analysis (MRA). The results showed that financial performance has a positive influence on firm value. CSR disclosure is able to moderate the relationship between financial performance and firm value, but managerial ownership as a GCG mechanism was unable to moderate the relationship between financial performance and firm value. The author's suggestion is to make the company more consistent and broader in CSR disclosure. CSR can build a good image of the company of investors and society, because by disclosing social information it will attract investors and have an impact on increasing the firm value.
\end{abstract}

Keywords :

Corporate Social Responsibility Disclosure, Good Corporate Governance, Financial Performance, Firm Value

Naskah diterima: 17 Mei 2019, direvisi: 01 Juli 2019, diterbitkan: 16 September 2019

ISSN: 2355-0295, e-ISSN: 2549-8932 


\section{PENDAHULUAN}

Perusahaan didirikan dengan tujuan untuk memperoleh keuntungan dan atau laba. Dengan laba atau keuntungan yang maksimal, perusahaan dapat mempertahankan kelangsungan hidupnya. Kinerja keuangan yang baik akan dapat membantu manajemen dalam mencapai tujuan perusahaan. Semakin tinggi kinerja keuangan perusahaan, maka akan semakin baik pula nilai perusahaan (saham) dimata investor dan tentunya akan berpengaruh pada nilai jual saham tersebut. Begitupun sebaliknya jika kinerja keuangan menunjukkan prospek yang buruk hal tersebut tentu akan mengurangi minat investor untuk membeli saham tersebut.

Salah satu rasio yang dapat digunakan untuk mengukur kinerja keuangan perusahaan adalah Return On Assets (ROA). ROA yang positif menunjukkan bahwa dari total aktiva yang digunakan untuk operasi perusahaan mampu memberikan laba bagi perusahaan. Sebaliknya jika ROA negatif menunjukkan total aktiva yang digunakan tidak memberikan keuntungan. Informasi dari laporan keuangan tersebut mempunyai fungsi selain sebagai sarana informasi juga sebagai alat pertanggung jawaban manajemen kepada pemilik perusahaan dan gambaran indikator keberhasilan perusahaan serta bahan dalam pertimbangan pengambilan keputusan. Para investor biasanya menggunakan informasi tersebut sebagai tolok ukur dalam melakukan transaksi jual - beli saham suatu perusahaan.

Tabel 1 berikut ini menunjukkan adanya fenomena gap dalam kondisi perusahaan manufaktur pada periode 2010-2015 di Bursa Efek Indonesia yang dilihat dari aspek Return On Assets (ROA) dan Nilai perusahaan (Tobins Q).
Tabel 1. Rata-rata Tobins Q dan ROA Perusahaan Manufaktur

\begin{tabular}{ccc}
\hline Tahun & Tobins Q & ROA \\
\hline $\mathbf{2 0 1 0}$ & 2,01646 & 0,063943 \\
\hline $\mathbf{2 0 1 1}$ & 1,991056 & 0,080806 \\
\hline $\mathbf{2 0 1 2}$ & 2,060043 & 0,071942 \\
\hline $\mathbf{2 0 1 3}$ & 2,048503 & 0,060337 \\
\hline $\mathbf{2 0 1 4}$ & 1,964074 & 0,041628 \\
\hline $\mathbf{2 0 1 5}$ & 1,723054 & 0,023753 \\
\hline \multicolumn{3}{l}{ Sumber : Data BEI diolah, 2017}
\end{tabular}

Berdasarkan tabel diatas, dapat diketahui tingkat kinerja keuangan yang diproksikan dengan ROA mengalami fluktuasi yang diikuti oleh Tobins Q. Secara teori kedua hal ini berkaitan erat. Modigliani dan Miller (1961) menjelaskan bahwa nilai perusahaan ditentukan oleh earnings power dari aset perusahaan. Hasil positif menunjukkan bahwa semakin tinggi earnings power semakin efisien perputaran asset dan atau semakin tinggi profit margin yang diperoleh perusahaan. Hal ini berdampak pada peningkatan nilai perusahaan. Sejalan dengan penelitian yang dilakukan oleh Modigliani dan Miller (1961), Ulupui (2007), Purwaningsih dan Wirajaya (2014), serta Putri dan Wirajaya (2017) menemukan hasil bahwa kinerja keuangan berpengaruh positif signifikan terhadap nilai perusahaan. Namun, hasil yang berbeda diperoleh oleh Suranta dan Pratana (2004) dimana kinerja keuangan justru berpengaruh negatif terhadap nilai perusahaan. Begitupula hasil penelitian yang dilakukan oleh Munawaroh (2014) yang menghasilkan pengaruh negatif kinerja keuangan terhadap nilai perusahaan. Sasongko dan Wulandari (2006) menunjukkan hasil penelitian bahwa kinerja keuangan tidak berpengaruh signifikan terhadap nilai perusahaan. Perbedaan hasil penelitian ini menunjukkan bahwa terdapat faktor lain yang mampu menggambarkan nilai perusahaan. Hal ini menunjukkan adanya faktor lain yang turut mempengaruhi hubungan kinerja keuangan terhadap nilai perusahaan. Oleh karena itu, pengungkapan Corporate Social Responsibility (CSR) dan Good Corporate Governance (GCG) 


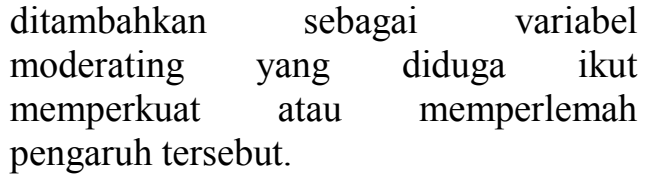

Corporate Social Responsibility diduga ikut berpengaruh, karena stakeholder theory berpandangan bahwa perusahaan harus melakukan pengungkapan sosial sebagai salah satu bentuk tanggung jawab kepada para stakeholder. Rustiarini (2010) menyatakan bahwa perusahaan akan mengungkapkan suatu informasi jika informasi tersebut dapat meningkatkan nilai perusahaan. Perusahaan dapat menggunakan informasi corporate social responsibility sebagai keunggulan kompetitif perusahaan. Perusahaan yang memiliki kinerja lingkungan dan sosial yang baik akan direspon positif oleh investor melalui peningkatan harga saham.

Hal ini menunjukkan bahwa selain melihat kinerja keuangan, pasar juga memberikan respons yang positif terhadap pengungkapan CSR yang dilakukan perusahaan (Yuniasih \& Wirakusuma, 2009). Perusahaan yang memiliki profitabilitas yang tinggi seharusnya melaksanakan corporate social responsibility secara transparan. Namun kenyataannya masih banyak perusahaan yang belum melaksanakannya secara transparan. Masyarakat berharap perusahaan tidak hanya bertangung jawab kepada investor dan manajemen, tetapi juga pada masyarakat yang lebih luas.

Selain pengungkapan CSR, isu lain yang diduga memperkuat pengaruh kinerja keuangan terhadap nilai perusahaan adalah mekanisme Good Corporate Governance. Wati et al (2016) dan Wati (2017) mengatakan bahwa mekanisme Good Corporate Governance dapat dilakukan melalui mekamisme eksternal dan internal. Mekanisme kontrol eksternal merupakan pengendalian perusahaan berdasarkan mekanisme pasar, sedangkan mekanisme internal adalah pengendalian yang dilakukan oleh dewan komisaris termasuk komitekomite di bawahnya, dewan direksi, manajemen dan para pemegang saham, atau melalui skema insentif yang menarik dan kompetitif untuk manajemen. Selain memiliki kinerja keuangan yang baik, perusahaan diharapkan juga memiliki tata kelola yang baik pula. Pengelolaan perusahaan akan mempengaruhi nilai perusahaan.

Masalah corporate governace muncul karena terjadinya pemisahan antara kepemilikan dan pengendalian perusahaan. Pemisahan ini didasarkan pada agency theory yang dalam hal ini manajemen cenderung akan meningkatkan keuntungan pribadinya daripada tujuan perusahaan. Perusahaan di Indonesia memiliki karakteristik yang tidak berbeda dengan perusahaan di Asia pada umumnya, dimana perusahaan dimiliki dan dikontrol oleh keluarga (Wati et. al., 2015). Meskipun perusahaan tersebut tumbuh dan menjadi perusahaan publik, namun kendali keluarga masih signifikan. Berdasarkan penelitian yang dilakukan oleh Claessens et all (2000) ditemukan bahwa pada tahun 1996 kapitalisasi pasar dari saham yang dikuasai oleh 10 perusahaan keluarga di Indonesia mencapai $57,7 \%$. Hal ini menunjukkan rendahnya struktur kepemilikan manajerial karena sebagian besar masih didominasi oleh keluarga. Pola dan kepemilikan usaha seperti ini akan mendorong praktik korupsi, kolusi, dan nepotisme, yang pada akhirnya akan menjatuhkan nilai perusahaan. Kepemilikan manajerial merupakan salah satu mekanisme GCG yang dapat mempengaruhi insentif bagi manajemen untuk melaksanakan kepentingan terbaik dari pemegang saham.

Berdasarkan paparan di atas, penelitian ini bertujuan untuk mengetahui bagaimana pengungkapan CSR dan GCG memoderasi pengaruh antara kinerja perusahaan terhadap nilai perusahaan pada perusahaan manufaktur di Indonesia.

KAJIAN LITERATUR

Corporate Social Responsibility (CSR)

Corporate Social Responsibility (CSR) 
merupakan sebuah gagasan yang tidak lagi dihadapkan pada tanggung jawab yang berpijak pada single bottom line saja, tetapi juga berpijak pada triple bottom line yaitu tanggung jawab terhadap masalah sosial dan lingkungan. Triple bottom line reporting merupakan laporan yang memberikan informasi mengenai pelaksanaan kegiatan ekonomi, sosial dan lingkungan dari sebuah entitas. Apabila prinsip triple bottom line dapat diimplementasikan dengan baik, maka akan menunjukkan akuntabilitas perusahaan tidak hanya untuk kegiatan ekonomi mereka, tetapi juga untuk pelaksanaan kegiatan sosial dan lingkungan (Deegan dalam Wati, 2018).

Beberapa tahun terakhir banyak perusahaan semakin menyadari pentingnya menerapkan program Corporate Social Responsibility sebagai bagian dari strategi bisnisnya. Salah satu yang menerapkannya adalah perusahaan industri atau manufaktur. Karakteristik utama perusahaan manufaktur adalah mengolah bahan baku menjadi barang atau produk jadi dan siap di jual ke konsumen. Perusahaan manufaktur tentu sangat concern terhadap masalah lingkungan. Program corporate social responsibility yang dijalankan oleh perusahaan manufaktur tentu akan menciptakan suatu kaitan emosional antara masyarakat dengan perusahaan apabila dikembangkan dengan baik, yang nantinya akan berdampak pada brand awareness, dan nantinya akan menciptakan keuntungan bagi perusahaan. Program kesehatan, aksi manusia dan peduli pendidikan di tanah air merupakan sedikit dari sekian banyak program yang dijalankan oleh perusahaan-perusahaan manufaktur. Hal ini tentu saja membawa dampak positif bagi perusahaan untuk mengembangkan usahanya dan mendapatkan citra yang baik di masyarakat.

Dalam melakukan penilaian luas pengungkapan CSR, item-item yang diberikan skor akan mengacu kepada indikator kinerja atau item yang disebutkan dalam GRI guidelines. Indikator kinerja dibagi menjadi 3 komponen utama, yaitu ekonomi, lingkungan dan sosial.

Total indikator kinerja mencapai 79 indikator, terdiri dari 9 indikator ekonomi, 30 indikator lingkungan hidup, 14 indikator praktek tenaga kerja, 9 indikator Hak Asasi Manusia, 8 indikator sosial atau kemasyarakatan, dan 9 indikator tanggung jawab produk.

\section{Good Corporate Governance}

Good corporate governance (GCG) dapat didefinisikan sebagai struktur, sistem, dan proses yang digunakan oleh organ-organ perusahaan sebagai upaya untuk memberikan nilai tambah perusahaan secara berkesinambungan dalam jangka panjang (IICG, 2010).

Prinsip-prinsip utama dari good corporate governance yang menjadi indikator, sebagaimana ditawarkan oleh Organization for Economic Cooperationand Development (OECD) adalah Fairness (Keadilan), Disclosure (Transparansi), Accountability (Akuntabilitas), Responsibility (Responsibilitas) dan Independency (Independen).

Dalam melaksanaan asas GCG, perusahaan harus dikelola secara independen. Independensi diperlukan untuk menghindari adanya potensi konflik kepentingan yang mungkin timbul oleh para pemegang saham mayoritas. Mekanisme ini menuntut adanya rentang kekuasaan antara komposisi komisaris, komite dalam komisaris, dan pihak luar seperti auditor. Keputusan yang dibuat dan proses yang terjadi harus obyektif tidak dipengaruhi oleh kekuatan pihak-pihak tertentu.

Menurut Wati (2017) mekanisme GCG dibagi menjadi dua, yaitu internal mechanism (mekanisme internal), seperti komposisi dewan direksi/komisaris, kepemilikan manajerial, dan kompensasi eksekutif. Mekanisme yang kedua yaitu external mechanism (mekanisme eksternal), seperti pengendalian oleh pasar dan level debt financing. Proksi yang digunakan GCG adalah 
kepemilikan manajerial sebagai mekanisme GCG internal. Kepemilikan manajerial adalah kepemilikan perusahaan dari pihak manajemen yang secara aktif ikut dalam pengambilan keputusan pada suatu perusahaan yang bersangkutan.

Kepemilikan saham yang besar dari segi ekonomisnya memiliki insentif untuk memonitor. Hal ini dapat terjadi karena dengan memberikan saham kepada manajemen maka manajemen sekaligus merupakan pemilik perusahaan sehingga akan bertindak demi kepentingan perusahaan, untuk itu kepemilikan manajerial dipandang sebagai alat untuk menyatukan kepentingan manajemen dengan pemilik (Shleifer dan Vishny, 1986).

\section{Kerangka Pikir Dan Hipotesis}

Teori yang dikemukakan oleh Modigliani dan Miller menyatakan bahwa nilai perusahaan ditentukan oleh earnings power dari aset perusahaan. Hasil positif menunjukkan bahwa semakin tinggi earnings power semakin efisien perputaran asset dan atau semakin tinggi profit margin yang diperoleh perusahaan. Hal ini akan berdampak pada nilai perusahaan. Hasil penelitian Ulupui (2007), Purwaningsih dan Wirajaya (2014), serta Putri dan Wirajaya (2017) menemukan bahwa kinerja keuangan perusahaan berpengaruh positif terhadap nilai perusahaan. Berdasarkan teori dan penelitian tersebut maka dibuat hipotesis berikut:

\section{H1 : Kinerja Keuangan berpengaruh Positif terhadap Nilai Perusahaan}

Hasil penelitian mengenai pengaruh ROA terhadap nilai perusahaan yang tidak konsisten menunjukkan adanya faktor lain yang turut menginteraksi, dimana Suranta dan Pratana (2004) dan Munawaroh (2014) menghasilkan pengaruh negatif kinerja keuangan terhadap nilai perusahaan, sementara Sasongko dan Wulandari (2006) menunjukkan hasil penelitian bahwa kinerja keuangan tidak berpengaruh signiffikan terhadap nilai perusahaan..
Hasil tersebut mendorong peneliti untuk memasukkan pengungkapan CSR sebagai variabel Moderating. Penelitian ini menggunakan pengungkapan CSR sebagai variabel moderating dengan pemikiran bahwa pasar akan memberikan apresiasi positif yang ditunjukkan dengan peningkatan harga saham perusahaan. Peningkatan ini akan menyebabkan nilai perusahaan juga meningkat. Hasil penelitian Yuniasih dan Wirakusuma (2009), Handoko (2010), Yendrawati dan Pratidina (2013) menemukan bahwa CSR mampu memoderasi hubungan antara kinerja keuangan dengan nilai perusahaan.. Berdasarkan uraian tersebut maka hipotesis yang diajukan adalah sebagai berikut:

\section{H2: Pengungkapan CSR memperkuat pengaruh kinerja keuangan terhadap nilai perusahaan.}

Jika perusahaan menerapkan sistem GCG, diharapkan kinerja perusahaan tersebut akan meningkat menjadi lebih baik, dengan meningkatnya kinerja perusahaan diharapkan juga dapat meningkatkan harga saham perusahaan sebagai indikator dari nilai perusahaan, sehingga nilai perusahaan meningkat. Nurlela dan Islahuddin (2008) menghasilkan bahwa kepemilikan manajerial serta interaksi antara corporate social responsibility dengan persentase kepemilikan manajemen secara simultan berpengaruh signifikan terhadap nilai perusahaan. Hasil penelitian Handoko (2010) juga mendukung bahwa GCG mampu memoderasi pada hubungan kinerja keuangan dengan nilai perusahaan. Berdasarkan uraian tersebut maka hipotesis alternatif yang diajukan adalah sebagai berikut:

\section{H3: Good Corporate Governance memperkuat pengaruh antara kinerja keuangan terhadap nilai perusahaan}

Perbedaan hasil penelitian mengenai pengaruh kinerja keuangan terhadap nilai perusahaan mengindikasikan terdapat variabel lain yang ikut mempengaruhi. 
Dalam hal ini penulis memasukkan variabel CSR dan GCG yang nantinya akan dapat dilihat apakah variabel ini akan mempengaruhi hubungan kinerja keuangan terhadap nilai perusahaan atau tidak. Oleh karena itu dapat digambarkan suatu kerangka pemikiran sebagai berikut:

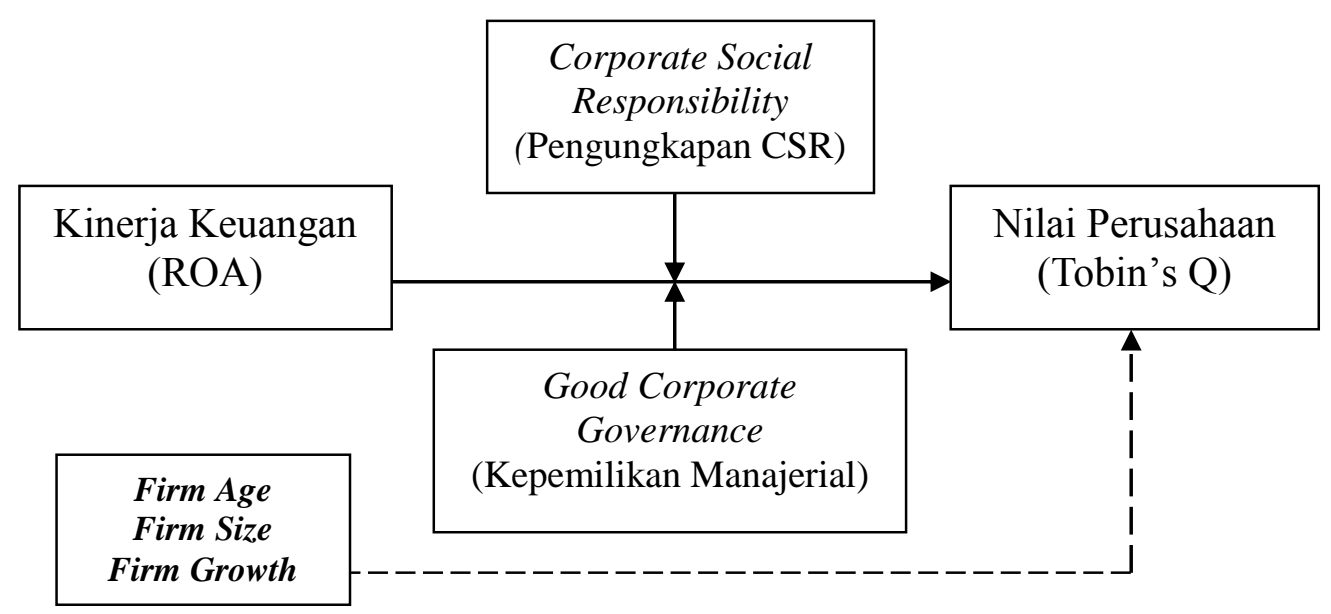

Gambar 1. Kerangka Pemikiran

Untuk menguji sensitivitas model (robust model), maka penulis menggunakan variabel kontrol yaitu firm age, firm size, dan firm growth.

\section{METODE PENELITIAN}

Populasi dalam penelitian ini adalah perusahaan-perusahaan manufaktur go public di Indonesia. Metode pengambilan sampel yang digunakan dalam penelitian ini adalah metode purposive sampling. Jumlah perusahaan yang memenuhi kriteria adalah 87 perusahaan dengan pengamatan dari tahun 2010-2015 (522 data panel). Dalam melakukan penilaian luas pengungkapan CSR, item-item yang akan diberikan skor akan mengacu kepada indikator kinerja atau item yang disebutkan dalam GRI guidelines.

Tabel 2. Operasional Variabel Penelitian

\begin{tabular}{|c|c|}
\hline Variabel & Deskripsi \\
\hline Dependen: & \\
\hline Nilai Perusahaan & Tobins $\mathrm{Q}=($ Market Value $+\mathrm{T}$. Debt $) / \mathrm{T}$. Asset \\
\hline Pengungkapan CSR & $C S D I i=\frac{\sum X i j}{}$ \\
\hline & $\operatorname{CSDIj}=\overline{n j}$ \\
\hline & Variabel Dummy : \\
\hline & $1:$ Jika mengungkapkan CSR \\
\hline & 0 : Jika tidak mengungkapkan CSR \\
\hline $\begin{array}{l}\text { Independen: } \\
\text { GCG (Kepemilikan Manajerial) }\end{array}$ & \% Kepemilikan saham (Direksi + Komisaris) \\
\hline $\begin{array}{l}\text { GCG (Kepemilikan Manajerial) } \\
\text { Return on Assets }\end{array}$ & Jumlah Saham Beredar \\
\hline $\begin{array}{l}\text { Return on Assets } \\
\text { Size }\end{array}$ & Earning After Tax dibagi Total Aset \\
\hline Size & Logaritme dari Total Asset \\
\hline Growth & $\Delta$ Penjualan $/$ Penjualan $t_{0}$ \\
\hline Firm Age & Umur perusahaan dimulai dari listing di pasar modal \\
\hline
\end{tabular}

Sumber: Diolah untuk Keperluan Penelitian

Untuk menguji hipotesis, maka digunakan model regresi sebagai berikut:

TOBINSQ $=\alpha+\beta 1 R O A i t+\beta 2 R O A * C S R i t+\beta 3 R O A * K M i t+\beta 4 A G E i t+\beta 5 S I Z E i t+\beta 6 G R O W T H i t+\varepsilon \ldots(1)$

TOBINSQ $=\alpha+\beta 1$ ROA $_{i t}+\beta 2 R O A * C S R_{i t}+\beta 3 R O A * K M_{i t}+\beta 4 A G E_{i t}+\beta 5 S I Z E i_{t}+\beta 6 G R O W T H i_{t}+\varepsilon$. 
Analisis atas koefisien regresi dilakukan dengan menganalisis signifikansi besaran regression weight. Analisis ini dilakukan untuk menunjukkan besaran dari efek menyeluruhdari satu variabel terhadap variabel lainnya (Wati, 2017). Keputusan menerima atau menolak hipotesis yang diajukan dilakukan dengan syarat Jika $t_{\text {hitung }}>t_{\text {tabel }}$ maka hipotesis nol $\left(\mathrm{H}_{0}\right)$ ditolak atau $\mathrm{H}_{\mathrm{a}}$ diterima, artinya terdapat pengaruh antara dua variabel secara statistik, begitu juga sebaliknya.

\section{PEMBAHASAN}

\section{Deskripsi Variabel}

Pada tabel 4.3 dibawah ini disajikan deskripsi variabel-variabel penelitian yaitu return on assets, Tobins Q, CSR, kepemilikan manajerial, age, size, growth. Jumlah perusahaan manufaktur sebanyak 87 sampel perusahaan dengan tahun pengamatan dari tahun 2010-2015 sehingga total tahun pengamatan adalah sebanyak 522 tahun perusahaan (data panel).

Tabel 3. Deskripsi Variabel Penelitian

\begin{tabular}{lcccc}
\hline $\begin{array}{l}\text { Variab } \\
\text { el }\end{array}$ & \multicolumn{4}{c}{$\mathbf{N}=\mathbf{5 2 2}$} \\
\cline { 2 - 5 } & $\begin{array}{c}\text { Mi } \\
\text { n }\end{array}$ & Max & Mean & $\begin{array}{c}\text { St.De } \\
\mathbf{v}\end{array}$ \\
\hline Tobins & 0,2 & 20,0 & 1,9672 & 2,631 \\
$\mathbf{Q}$ & 7 & 5 & & 1 \\
\hline ROA & - & 0,66 & 0,0571 & 0,111 \\
& 0,6 & & & 8 \\
& 2 & & & \\
\hline CSR & 0 & 0,85 & 0,1713 & 0,142 \\
& & & & 5 \\
\hline KM & 0 & 0,70 & 0,0297 & 0,092 \\
& & & & 5 \\
\hline Age & 0 & 38,0 & 18,166 & 7,462 \\
& & 0 & 7 & 1 \\
\hline Size & 4,8 & 8,39 & 6,2114 & 0,670 \\
& 9 & & & 1 \\
\hline Growth & - & 5,95 & 0,1296 & 0,400 \\
& 0,7 & & & 4 \\
& 3 & & & \\
\hline
\end{tabular}

Sumber: Data BEI diolah, 2017

Berdasarkan data pada tabel 3, terlihat bahwa nilai minimum Tobins $\mathrm{Q}$ sebesar 0,27 dan maksimum sebesar 20,05. Sementara nilai standard deviasi Tobins Q sebesar sebesar 2,6311, dengan nilai rata-rata Tobins $\mathrm{Q}$ yang dimiliki perusahaan manufaktur periode 20102015 adalah 1,9672. Nilai terendah dimiliki oleh PT. Nusantara Inti Corpora Tbk pada tahun 2010 , dan yang tertinggi PT. Astra International Tbk pada tahun 2010. Tobins Q yang memiliki nilai lebih dari satu mempunyai makna bahwa perusahaan mampu menghasilkan earning dengan tingkat return yang sesuai dengan harga perolehan asetnyaasetnya.

Nilai ROA minimum sebesar $-0,62$ dan maksimum sebesar 0,66 . Sementara nilai rata-rata ROA sebesar 0,0571 dan nilai standard deviasi sebesar 0,1118 . Nilai terendah dimiliki oleh PT. Kertas Basuki Rachmat Indonesia Tbk pada tahun 2010, sedangkan nilai ROA tertinggi dimiliki oleh PT. Multi Bintang Indonesia Tbk pada tahun 2013.

Nilai CSR minimum sebesar 0 dan maksimum sebesar 0,85 . Sementara nilai rata-rata CSR sebesar 0,1713 dan nilai standard deviasi sebesar 0,1425 . Nilai terendah dimiliki oleh PT. Alakasa Industrindo Tbk, PT. Alumindo Light Metal Industry Tbk, PT. Indo Kordsa Tbk, sementara nilai tertinggi dimiliki oleh PT. Indofood CBP Sukses Makmur Tbk..

Nilai KM minimum sebesar 0 dan maksimum sebesar 0,70 . Sementara nilai rata-rata KM sebesar 0,0297 dan nilai standard deviasi sebesar 0,0925. Nilai kepemilikan manajerial tertinggi dimiliki oleh PT. Sat Nusapersada Tbk.

Nilai age minimum sebesar 0 dan maksimum sebesar 38. Sementara nilai rata-rata age sebesar 18,1667 dan nilai standard deviasi sebesar 7,4621.

Nilai size minimum sebesar 4,89 dan maksimum sebesar 8,39 . Sementara nilai rata-rata size sebesar 6,2114 dan nilai standard deviasi sebesar 0,6701. Nilai tertinggi dimiliki oleh PT. Astra International Tbk. Dan nilai terendah dimiliki oleh PT. Lionmesh Prima Tbk. Nilai growth minimum sebesar $-0,73$ dan maksimum sebesar 5,95. Sementara nilai rata-rata growth sebesar 0,1296 dan nilai standard deviasi sebesar 0,4004. Nilai 
tertinggi dan terendah growth dimiliki oleh PT. Kertas Basuki Rachmat Indonesia Tbk., yaitu terendah pada tahun 2013 dan tertinggi tahun 2015.
Untuk memperjelas gambaran tiap-tiap variabel, berikut rata-rata variabel tiap periode:

Tabel 4.Rata-rata Variabel Penelitian Periode 2010-2015

\begin{tabular}{cccccccc}
\hline Tahun & Tobins Q & ROA & CSR & KM & Age & Size & Growth \\
\hline $\mathbf{2 0 1 0}$ & 2,01646 & 0,063943 & 0,101702 & 0,029165 & 15,66667 & 6,065368 & 0,144128 \\
\hline $\mathbf{2 0 1 1}$ & 1,991056 & 0,080806 & 0,121199 & 0,029051 & 16,66667 & 6,135222 & 0,229621 \\
\hline $\mathbf{2 0 1 2}$ & 2,060043 & 0,071942 & 0,171977 & 0,02738 & 17,66667 & 6,191796 & 0,148161 \\
\hline $\mathbf{2 0 1 3}$ & 2,048503 & 0,060337 & 0,192783 & 0,027882 & 18,66667 & 6,256899 & 0,140823 \\
\hline $\mathbf{2 0 1 4}$ & 1,964074 & 0,041628 & 0,214608 & 0,032594 & 19,66667 & 6,292476 & 0,065491 \\
\hline $\mathbf{2 0 1 5}$ & 1,723054 & 0,023753 & 0,22552 & 0,031928 & 20,66667 & 6,326351 & 0,049367 \\
\hline
\end{tabular}

Sumber : Data BEI diolah, 2017

Berikut penjelasan gambaran rata-rata variabel dari tahun ke tahun.

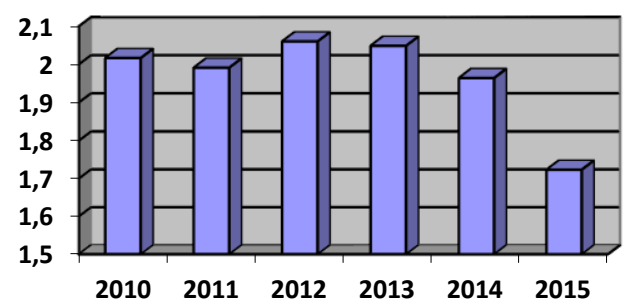

Grafik 1. Rata-rata Tobins Q tahun 2010-2015

Terlihat pada grafik diatas rata-rata Tobins Q perusahaan manufaktur dari tahun 2010-2015 bernilai positif dan diatas satu, artinya perusahaan manufaktur memiliki potensi pertumbuhan yang tinggi. Dari tahun 2010 sampai tahun 2015, rata-rata Tobins Q mengalami fluktuasi. Nilai Tobins Q terendah terjadi pada tahun 2015, hal ini menunjukkan bahwa krisis global berpengaruh terhadap nilai perusahaan manufaktur.

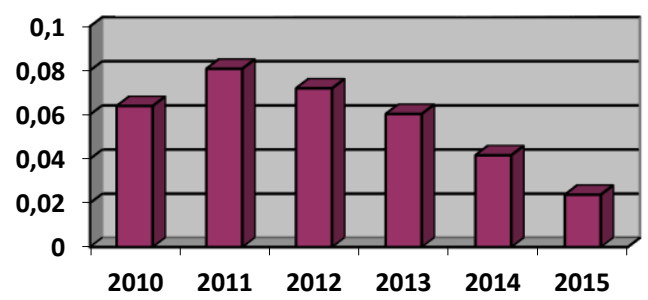

Grafik 2. Rata-rata ROA tahun 2010-2015

Dari grafik 2 diatas rata-rata return on assets perusahaan manufaktur mengalami kenaikan dari tahun 20102012. Namun di tahun 2012-2015 trend return on assets mengalami penurunan. Nilai rata-rata return on asset terkecil terjadi di tahun 2015, hal ini merupakan imbas dari krisis global yang terjadi di tahun 2015.

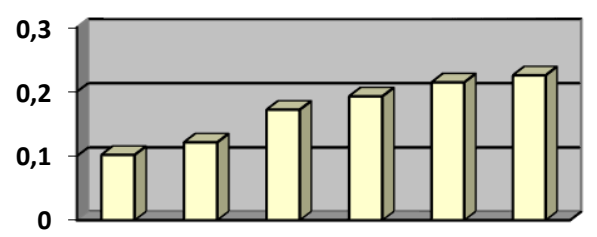

Grafik 3. Rata-rata CSR tahun 20102015

Terlihat pada grafik 3 bahwa rata-rata pengungkapan CSR tiap tahunnya mengalami kenaikan yang signifikan. Hal ini merupakan kesadaran perusahaan manufaktur untuk terus melakukan dan mengungkapkan CSR demi menarik minta investor yang nantinya akan berdampak pada meningkatnya nilai perusahaan. Berikut dibawah ini ditampilkan rata-rata pengungkapan CSR berdasarkan Global Reporting Index (GRI).

Tabel 5. Indeks pengungkapan CSR

\begin{tabular}{rccc}
\hline Variabel & \multicolumn{3}{c}{$\mathbf{N}=\mathbf{5 2 2}$} \\
\cline { 2 - 4 } & Min & Max & Mean \\
\hline Ekonomi & 0 & 0,78 & 0,2146 \\
\hline Lingkungan & 0 & 1,00 & 0,1866 \\
\hline $\begin{array}{r}\text { Tenaga } \\
\text { Kerja }\end{array}$ & 0 & 0,86 & 0,1762 \\
\hline
\end{tabular}




\begin{tabular}{rrrr}
\hline HAM & 0 & 0,67 & 0,0605 \\
\hline Sosial & 0 & 0,75 & 0,2251 \\
\hline Produk & 0 & 1,00 & 0,1324
\end{tabular}

Sumber data : Data GRI diolah, 2017

Berdasarkan tabel 5 diatas didapatkan bahwa tema CSR yang paling paling banyak diungkapkan oleh perusahaan manufaktur adalah CSR bidang lingkungan dan produk. Hal ini sejalan dengan sektor manufaktur yang bersinggungan langsung dengan lingkungan hidup, dimana perusahaan wajib menjaga dan melindungi lingkungan sekitar dari dampak buruk yang dihasilkan oleh industri. Begitu pula dengan tema produk, perusahaan manufaktur harus memastikan bahwa produk yang dihasilkan sudah memenuhi standar kesehatan dan keamanan produk.

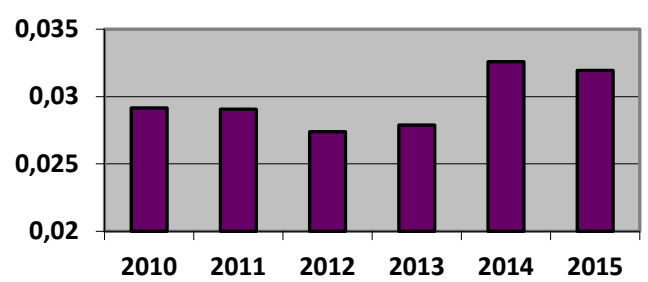

Grafik 4. Rata-rata GCG tahun 20102015

Kepemilikan manajerial mengalami fluktuasi dari tahun ke tahun. Nilai ratarata $\mathrm{KM}$ terendah terjadi pada tahun 2012. Dan nilai KM tertinggi terjadi pada tahun 2014. Efek dari pemilu dan krisis global yang terjadi di tahun 2014 dan 2015 justru tidak berimbas pada kepemilikan saham manajerial. Kepemilkan saham di tahun tersebut justru mengalami trend kenaikan.

\section{Pengujian Hipotesis Penelitian}

Pengujian hipotesis dalam penelitian ini menggunakan software eviews versi 9 . Pengujian dilakukan dengan metode Random Effect model menggunakan General Least Square (weighted cross section) karena data panel dalam penelitian ini mempunyai jumlah waktu lebih kecil dibandingkan dengan jumlah individu (Wati, 2017) serta mengandung heteroskedastisitas. Tabel 4.2 berikut ini menjelaskan hasil pengujian hipotesis:

Tabel 6. Hasil Pengujian Model Penelitian

\begin{tabular}{|c|c|c|c|c|c|}
\hline Variabel & Prediksi & Main Model & Hipotesis & $\begin{array}{l}\text { Robust } \\
\text { Model }\end{array}$ & Hipotesis \\
\hline Constant & & $-0,0782$ & & 0,9835 & \\
\hline$R O A$ & $\beta$ Positif & $\begin{array}{l}1,1049 * * \\
(2,323)\end{array}$ & Didukung & $\begin{array}{l}1,29 * * * \\
(2,641)\end{array}$ & Didukung \\
\hline$R O A^{*} C S R$ & $\beta$ Positif & $\begin{array}{l}42,543 * * * \\
(13,723)\end{array}$ & Didukung & $\begin{array}{l}42,4913^{* * *} \\
(13,477)\end{array}$ & Didukung \\
\hline$R O A^{*} K M$ & $\beta$ Positif & $\begin{array}{l}-3,5818 \\
(-0,5757)\end{array}$ & $\begin{array}{l}\text { Tidak } \\
\text { Didukung }\end{array}$ & $\begin{array}{l}-8,5079 \\
(-1,0423)\end{array}$ & $\begin{array}{l}\text { Tidak } \\
\text { Didukung }\end{array}$ \\
\hline Age & $\beta$ Positif & $\begin{array}{l}0,0094 * * * \\
(3,3111)\end{array}$ & Didukung & & \\
\hline Size & $\beta$ Positif & $\begin{array}{l}0,1428 * * * \\
(4,6634)\end{array}$ & Didukung & & \\
\hline Growth & $\beta$ Positif & $\begin{array}{c}0,0250 \\
(0,3851)\end{array}$ & $\begin{array}{l}\text { Tidak } \\
\text { Didukung }\end{array}$ & & \\
\hline$R^{2}$ & & 0,5284 & & 0,4802 & \\
\hline Adjusted $R^{2}$ & & 0,5229 & & 0,4772 & \\
\hline Fstat & & 96,15 & & 159,497 & \\
\hline
\end{tabular}

Sumber: Data diolah, 2017

***Didukung secara statistik pada alpha $1 \%, * *$ pada alpha $5 \%,{ }^{*} 10 \%$ 
Hasil pengujian hipotesis pada tabel 6 menunjukkan bahwa terdapat pengaruh positif signifikan antara kinerja keuangan terhadap nilai perusahaan. Nilai 1,1049 pada koefisien regresi menunjukkan bahwa setiap kinerja keuangan naik 1 maka nilai perusahaan akan naik sebesar 1,1049 dan sebaliknya. Hasil penelitian mendukung hipotesis pertama dimana terdapat pengaruh positif dan signifikan kinerja keuangan terhadap nilai perusahaan. Hasil yang positif menunjukkan bahwa semakin tinggi earning power semakin efisien perputaran aset atau semakin tinggi profit margin yang diperoleh oleh perusahaan. Hal ini berdampak pada peningkatan nilai perusahaan yang nantinya akan mempengaruhi return saham satu tahun kedepan. Hasil ini mendukung penelitian yang dilakukan oleh Yuniasih dan Wirakusuma (2007), Ulupui (2007), Purwaningsih dan Wirajaya (2014), serta Putri dan Wirajaya (2017) bahwa terdapat pengaruh positif antara kinerja perusahaan terhadap nilai perusahaan.

Koefisien regresi yang diperoleh dari interaksi ROA dengan CSR terhadap nilai perusahaan adalah sebesar 42,543 dengan nilai signifikansi $5 \%$ menyatakan bahwa terdapat pengaruh positif dan signifikan antara interaksi CSR terhadap kinerja keuangan dengan nilai perusahaan. Hasil ini mendukung hipotesis penelitian kedua dimana CSR memperkuat pengaruh kinerja keuangan terhadap nilai perusahaan. Hasil ini sesuai dengan penelitian sebelumnya yaitu Yuniasih dan Wirakusuma (2009), Handoko (2010), Yendrawati dan Pratidina (2013). Hasil penelitian menunjukkan bahwa pengungkapan CSR dapat menjadi bahan pertimbangan investor sebelum berinvestasi, karena didalamnya mengandung informasi sosial yang dilakukan perusahaan. Hal ini menunjukkan bahwa selain melihat kinerja keuangan, pasar juga memberikan respons yang positif terhadap pengungkapan CSR yang dilakukan perusahaan (Wirakusuma dan Yuniasih,2009). Dalam UU Perseroan
Terbatas No. 40 tahun 2007 Bab IV mengenai Tanggung Jawab Sosial dan Lingkungan disebutkan bahwa perseroan yang menjalankan kegiatan usahanya di bidang dan/atau berkaitan dengan sumber daya alam wajib melaksanakan tanggung jawab sosial dan lingkungan. Hal ini tentu menjadi pertimbangan investor dalam berinvestasi. Karena jika perusahaan tidak melakukan atau mengungkapkan CSR, maka perusahaan tersebut akan dikenakan sanksi sesuai ketentuan peraturan perundangundangan. Sanksi tersebut nantinya akan berdampak pada menurunnya citra perusahaan dan berdampak pada menurunnya nilai perusahaan dikarenakan para investor takut untuk menanamkan sahamnya di perusahaan yang memiliki citra yang buruk. Hal ini lah yang mendasari pentingnya pengungkapan CSR perusahaan dimata para investor.

Koefisien regresi yang diperoleh dari Interaksi ROA dengan GCG terhadap nilai perusahaan adalah sebesar $-3,5818$ dengan nilai $t_{\text {statistik }}-0,5757$. Jadi dapat dinyatakan bahwa tidak terdapat pengaruh signifikan antara interaksi ROA dengan GCG terhadap nilai perusahaan. Dengan demikian hasil empiris ini tidak mendukung hipotesis penelitian yang ketiga, dimana GCG tidak mampu memperkuat hubungan kinerja keuangan terhadap nilai perusahaan. Dari hasil tersebut dapat disimpulkan bahwa hipotesis ketiga (H3) ditolak. Hasil penelitian ini sesuai dengan penelitian Herawati (2006), Pertiwi dan Pratama (2012), serta Putri dan Wirajaya (2017) yang menunjukkan bahwa Good Corporate Governance tidak memperkuat pengaruh kinerja keuangan terhadap nilai perusahaan. Perbedaan kepentingan antara manajer dan pemegang saham akan menimbulkan agency conflict, hal tersebut terjadi karena manajer mengutamakan kepentingan pribadi, sebaliknya pemegang saham tidak menyukai kepentingan pribadi dari manajer karena apa yang dilakukan manajer tersebut 
akan menambah biaya bagi perusahaan sehingga menyebabkan penurunan keuntungan perusahaan dan berpengaruh terhadap harga saham sehingga menurunkan nilai perusahaan (Jensen dan Meckling, 1976 ). Selain itu trend perusahaan di Indonesia yang mayoritas masih dimiliki oleh keluarga mengakibatkan sulitnya manajer dalam menentukan kebijakan karena hak voting dan power yang mayorias dimiliki oleh pemilik dalam penentuan kebijakan sehingga kebijakan yang diambil terkadang bertentangan dengan kepentingan manajer. hal ini didukung oleh rata-rata kepemilikan manajerial yang hanya sebesar 0,0297. Dengan ratarata kepemilikan sebesar itu tentu akan sulit bagi manajer untuk membuat kebijakan atau menentukan tujuan perusahaan jika dihadapkan pada pemilik saham mayoritas

Dari hasil tabel 6 diatas terdapat pengujian variabel kontrol age, dan size berpengaruh positif signifikan terhadap nilai perusahaan. Hasil ini menunjukkan bahwa semakin usia perusahaan meningkat maka nilai perusahaan juga akan meningkat. Begitu juga dengan size perusahaan, semakin besar size perusahaan semakin besar pula nilai perusahaan. Berbeda dengan variabel age dan size, variabel growth justru menujukkan pengaruh positif namun tidak signifikan terhadap nilai perusahaan. Dilihat dari robust test model, dimana variabel kontrol yaitu age, size, dan growth dihilangkan, menunjukkan hasil pengujian yang konsisten dengan model penelitian utama, dimana kinerja keuangan berpengaruh positif terhadap nilai perusahaan. Begitu juga dengan hasil konsisten yang didapat antara interaksi kinerja keuangan dengan CSR maupun interaksi kinerja keuangan dengan GCG. Hal ini menunjukkan bahwa hasil penelitian ini dikatakan robust atau kokoh.

Nilai adjusted Rsquare (determinasi) sebesar 0,5229, artinya nilai perusahaan dipengaruhi oleh kinerja keuangan, CSR, dan GCG sebesar 52,29\% dan sisanya sebesar $47,71 \%$ dipengaruhi oleh faktor lain diluar penelitian. Variabel yang memberikan pengaruh terkecil terhadap nilai perusahaan adalah $\mathrm{KM}$ yang memoderasi ROA dengan nilai koefisien regresi -3,5818. Hal ini dikarenakan persentase kepemilikan manajerial yang relatif kecil di perusahaan. Berdasarkan penelitian yang dilakukan oleh Claessens et al. (2002) ditemukan bahwa kapitalisasi pasar dari saham yang dikuasai oleh 10 perusahaan keluarga di Indonesia mencapai $57,7 \%$. Hal ini menunjukkan rendahnya struktur kepemilikan manajerial karena sebagian besar masih didominasi oleh keluarga.

\section{PENUTUP}

Hasil penelitian menunjukkan bahwa kinerja keuangan berpengaruh positif terhadap nilai perusahaan. Semakin tinggi kinerja keuangan maka semakin tinggi nilai perusahaan. Pengungkapan Corporate Social Responsibility (CSR) berpengaruh signifikan terhadap hubungan kinerja keuangan terhadap nilai perusahaan. Hal ini dikarenakan pengungkapan CSR dapat membangun citra baik perusahaan dimata investor maupun masyarakat. Perusahaan yang mengungkapkan informasi sosial nya akan lebih menarik dimata investor dan pada akhirnya akan meningkatkan nilai perusahaan. Kepemilikan manajerial tidak mampu memoderasi hubungan antara kinerja keuangan dengan nilai perusahaan. Hal ini dikarenakan adanya agency conflict dan juga proporsi saham yang dimiliki oleh dewan direksi maupun komisaris sangat kecil dengan rata-rata hanya 0,0297. Dengan begitu akan sulit bagi manajerial untuk memegang kontrol dan kendali terhadap keputusan strategis perusahaan. Selain itu mayoritas perusahaan di Indonesia juga masih didominasi oleh kepemilikan keluarga.

Berdasarkan hasil penelitian dan temuan model dalam penelitian ini, ada beberapa masukan atau saran. Untuk manajemen diharapkan terus mampu meningkatkan kinerja keuangan perusahaan agar nilai perusahaannya terus meningkat. Perusahaan juga diharapkan selalu 
konsisten dalam melakukan pengungkapan CSR dengan cakupan yang lebih luas dalam rangka meningkatkan brand image dan nilai perusahaan. Penelitian selanjutnya diharapkan dapat memperluas lingkup penelitian, tidak hanya pada perusahaan industri saja tetapi juga melibatkan sektor yang lain agar mencerminkan reaksi pasar modal secara keseluruhan. Penelitian selanjutnya hendaknya menggunakan proksi lain dari kinerja keuangan maupun good corporate governance dan menambah variabel independen lainnya yang dapat mempengaruhi nilai perusahaan.

\section{REFERENSI}

Claessens, S., Djankov, S., Fan, J. P., \& Lang, L. H. (2002). Disentangling the incentive and entrenchment effects of large shareholdings. The journal of finance, 57(6), 27412771.

Handoko, Yuanita. 2010, Pengaruh Kinerja Keuangan Terhadap Nilai Perusahaan Dengan Pengungkapan Corporate Social Responsibility Dan Good Corporate Governance Sebagai Variabel Pemoderasi, Fakultas Ekonomi. Universitas Gunadarma.

Herawati, V. (2008). Peran Praktek Corporate Governance Sebagai Moderating Variable dari Pengaruh Earnings Management Terhadap Nilai Perusahaan. Jurnal Akuntansi Dan Keuangan, Vol. 10, No. 2, November, Halaman 97-108.

Jensen, M. C., \& Meckling, W. H. (1976). Theory of the firm: Managerial behavior, agency costs and ownership structure. Journal of Financial Economics, 3(4), pp. 305360.

Miller, M. H., \& Modigliani, F. (1961). Dividend policy, growth, and the valuation of shares. the Journal of Business, 34(4), 411-433.

Mohamed, M. B., \& Sawandi, N. B. (2007). Corporate Social Responsibility (CSR) activities in mobile telecommunication industry: case study of Malaysia. In European Critical Accounting Conference, Scotland, UK.

Munawaroh, A., \& Priyadi, M. P. (2014). Pengaruh profitabilitas terhadap nilai perusahaan dengan corporate social responsibilty sebagai variabel moderating. Jurnal Ilmu \& Riset Akuntansi, 3(4), 1-17.

Nurlela, I. (2008). Pengaruh Corporate Social Responsibility Terhadap Nilai Perusahaan Dengan Prosentase Kepemilikan Manajemen Sebagai Variabel Moderating. Simposium Nasional Akuntansi XI.

Pertiwi, T. K., \& Pratama, F. M. I. (2012). Pengaruh Kinerja Keuangan Good Corporate Governance Terhadap Nilai Perusahaan Food and Beverage. Jurnal manajemen dan kewirausahaan, 14(2), 118-127.

Purwaningsih, N. K. I., \& Wirajaya, I. Pengaruh kinerja keuangan pada nilai perusahaan dengan pengungkapan corporate social responsibility sebagai variabel pemoderasi. E-Jurnal Akuntansi, 7(3), 598-613.

Putri, I.K.H.K. \& Wirajaya, I. 2017. Pengaruh Kinerja Keuangan Pada Nilai Perusahaan Dengan Good Corporate Governance Sebagai Variabel Pemoderasi. E-Jurnal Akuntansi. Vol. 21.1. Halaman 1-28.

Rustiarini, N. W. (2010). Pengaruh Corporate Governance pada Hubungan Corporate Social Responsibility dan Nilai Perusahaan. Simposium Nasional Akuntansi XIII, 15(1), 1-24.

Sasongko, N., \& Wulandari, N. (2006). Pengaruh EVA dan rasiorasio profitabilitas terhadap harga saham. Jurnal Empirika, 19(1), 64-80.

Ulupui, I. G. (2007). Analisis pengaruh rasio likuiditas, leverage, aktivitas, dan profitabilitas terhadap return saham (studi pada perusahaan makanan dan minuman dengan 
kategori industri barang konsumsi di BEJ). Jurnal Ilmiah Akuntansi dan Bisnis, 2(1). Halaman 88-102.

Undang-Undang Republik Indonesia. (2007). UU Nomor 40 tahun 2007 Pasal 74 tentang Perseroan Terbatas

Wati, M. L. N., Primiana, I., \& Sudarsono, R. 2015. Political connections and controlling shareholder on Indonesia conglomerates. Proceedings of International Conference on Advanced Research Business and Social Sciences (ICARBSS) 2015 Kuala Lumpur, Malaysia, pp 133142.

Wati, L.N., Rachmat Sudarsono, S.E., Si, M. and Erie Febrian, S.E. 2016. Corporate governance on conglomerates pollitically connected. International Journal of Business, Economics and Law, 10(1), pp.23-31.

Wati, L. N. 2017. Board of commissioner's effectiveness on politically connected conglomerates: Evidence from Indonesia. Pertanika Journal Social Sciences \& Humanities, 25(S), pp. 255-270.

Wati, L. N. (2017). Metodologi Penelitian Bisnis Terapan Aplikasi SPSS, EVIEWS, Smart PLS, dan AMOS. Mujahid Press. Bandung.

Wati, L.N. (2018). Faktor-Faktor Yang Mempengaruhi Corporate Social Responsibility Dengan GRI 3 . Ecodemica Journal, Vol. 2 No. 2, Page 240-252.

Yendrawati, R., \& Pratidina, D. 2013. Pengaruh Kinerja Keuangan Terhadap Nilai Perusahaan Dengan Corporate Social Responsibility Dan Kepemilikan Institusional Sebagai Variabel Pemoderasi. Jurnal UNISIA. Vol. XXXV, No. 78.

Yuniasih, Ni Wayan dan Wirakusuma, Made Gede, 2009,"Pengaruh Kinerja Keuangan Terhadap Nilai Perusahaan Dengan Pengungkapan Corporate Social Responsibility Dan Good Corporate Governance Sebagai Variabel Pemoderasi", Jurnal Ilmiah Akuntansi dan Bisnis
Vo. 4, Januari. Halaman 1-10.

\section{BIODATA PENULIS}

Dr. Lela Nurlaela Wati, S.E., M.M. menyelesaikan pendidikan S3 Doktor Ilmu Manajemen di Universitas Padjadjaran konsentrasi Manajemen Keuangan pada tahun 2016. Dosen di STIE Muhammadiyah Jakarta (Associate Professor). Penulis tertarik melakukan penelitian di bidang keuangan perusahaan, perbankan, pasar modal, atau terkait dengan manajemen keuangan.

ORCID ID: https://orcid.org/0000-00017046-612X

Bono Prambudi adalah dosen di STIE Muhammadiyah Jakarta. 